\title{
E2F2 Gene
}

National Cancer Institute

\section{Source}

National Cancer Institute. E2F2 Gene. NCI Thesaurus. Code C96000.

This gene plays a role in both cell cycle control and transcriptional regulation. 